\title{
Distance Learning In Accounting Courses From The Student's Perspective (1999-2006)
}

James P. Beaghan, (E-mail: beaghanj@cwu.edu), Central Washington University

\begin{abstract}
Universities throughout the nation are faced with the reality of an increase in demand from placebound, adult working students who live and work in locations that may be hundreds of miles from traditional college campuses, and require a less centralized mode of course instruction. At the same time technological advances are now available that provide universities with a wide range of instructional modes of instruction that include interactive television (ITV) with real time audio and visual at a number of decentralized classroom sites, live and remote. Distance learning/distance education (DE) technologies currently allow an instructor to deliver university course instruction to several remote sites in real time via live ITV, while teaching a class to students in a traditional university classroom setting. While there are a growing number of studies on distance education, there are relatively few research studies on student satisfaction, with existing research showing mixed results (Anderson, Banks and Leary, 2002, Beaghan, 2006), and very little research on the effect of two-way ITV on university accounting and business course instruction (Arndt and Lafollette, 1991, Pirrong and Lathen, 1990, Seay and Milkman, 1994). University accounting course instruction may involve a number of different modes of instruction that include live instruction, online instruction and distance education. This research study looks at differences in student perception of value and satisfaction with quantitatively oriented courses delivered via ITV between groups of students in accounting courses taught between 1999 and 2006. Specifically this study looks at differences in attitudes between two groups of students, live and remote, and whether students who receive course instruction at remote sites via ITV perceive the same degree of value and satisfaction as do students receiving the same course instruction live and in real time.
\end{abstract}

\section{INTRODUCTION}

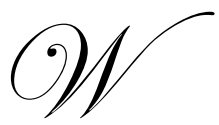

ith an increased number of non-traditional students throughout the United States, state governments and university administrators are developing strategies to meet the growing demand for university course instruction at remote sites that are more convenient to placebound, adult, working students.

Over the last decade technological advances have provided universities with a number of course instruction delivery options to meet the special needs of the non-traditional student that include live instruction, online instruction, and a variety of distance education/distance learning technologies that include interactive television (ITV).

ITV technology makes it possible for the university to deliver course instruction live and in real time to any number of remote sites with one instructor. Students at remote sites are able to see and hear the instructor and participate fully in class, while the instructor is able to see and communicate with remote site students in real time. Taped lectures are available to remote site students in the event of technological problems. Students at remote sites must have the ability to adapt to a different mode of instruction that requires them to interact with a televised image 
of the course instruction on a TV monitor, and be able to respond with interactive audio using microphones at their desks.

The typical ITV distance education classroom is equipped with one/two remote controlled television cameras, one/two large-screen monitors, one document camera, one videocassette recorder, and DE technology support personnel. ITV technology may include satellite, fiber optics, coaxial cable, microwave, high speed telephone lines, and digital compression equipment. Although the total cost of equipping a distance education classroom is typically double the cost of one traditional classroom (Swift, Wilson and Wayland, 1997) and may exceed $\$ 100,000$ per DE classroom, the university may be able to offset this expense with the capability of providing instruction to multiple sections of the same course with one instructor.

A state university in the Pacific Northwest currently serves a student population that includes typical college aged students attending class at the main campus in a traditional university setting. The university has also been tasked to serve a growing number of non-traditional, placebound, adult working students, who live and work in locations that may be 100 miles from the main campus. The university has established six extended degree centers throughout the region to serve non-traditional students, and has equipped classrooms at these centers with ITV technology that delivers distance education course instruction in real time. The instructor typically will provide live instruction to students in a classroom (usually on the main campus), as well as to students attending class at a number of remote sites throughout the region.

Each distance education classroom is equipped with two large screen television monitors at the front and rear of the classroom, a projection screen, a document camera, a videocassette recorder, and microphones at each desk.

Previous studies on DE are mixed with some students at remote sites experiencing less ability to ask questions, less involvement and less overall satisfaction/enjoyment with the course (Ritchie and Newby, 1989), while other studies show students in DE classes reporting more favorable attitudes and a willingness to take additional DE classes in the future (Swift, Wilson and Wayland, 1997). With a lack of research on ITV (DE) student satisfaction existing literature shows mixed results (Anderson, Banks and Leary 2002, Beaghan 2006), with only a few studies on the effect of two-way ITV on university business course instruction (Arndt and Lafollette, 1991, Pirrong and Lathen, 1990, Seay and Milkman, 1994).

The purpose of this research study is to assess student attitudes and perceptions in three upper division quantitatively oriented accounting courses taught by instructors at a Pacific Northwest university from 1999 to 2006 via ITV in real time to two student groups: traditional college aged students typically receiving course instruction live in a traditional college classroom setting, and non-traditional, adult, working students typically receiving the same course instruction in real time via two-way interactive television at remote classroom sites throughout the region.

Research questions included whether students receiving quantitatively oriented course instruction at remote sites via ITV perceive the same degree of satisfaction and value with the course as do students receiving the same course live in a typical classroom setting on a traditional college campus in real time.

\section{LITERATURE REVIEW}

Swift, Wilson and Wayland (1997) provide an overview of distance learning issues and concerns in business courses. They report that university interest in distant learning is increasing with the increased numbers of non-traditional adult students, and that although off campus instruction to meet the needs of this student group involves commuting and other related expenses, distance learning can be a more costly alternative with technology and supplementary operating costs often exceeding $\$ 75 \mathrm{~K} /$ classroom. University concerns include the cost of additional administrative and technical infrastructure to assist DE faculty and students, faculty training, intellectual copyrights, faculty compensation and workload reduction. Faculty concerns include the need to redesign DE 
courses, additional prep time, technology failures, visits and office hours at remote sites, and the administration of exams.

Anderson, Banks and Leary (2002), Beaghan (2006) cite a lack of research on student satisfaction with distance learning course instruction via live interactive television in real time. They report that existing research on ITV shows mixed results, with Silvernail and Johnson (1990 and 1992) showing no significant difference in student satisfaction (live vs. remote), while other studies, Egan, Welch, et al. (1992), Gunawardena (1992), and Kochman (1998) show less student satisfaction at remote sites due to limited instructor interaction. Additional inconclusive research cited includes Thomerson (1995) and Zarghami (1998) finding remote site students more satisfied with distance learning due to convenience, while Clow (1999) reports that remote site students are less satisfied due to lack of instructor enthusiasm or awareness of student problems.

In their study of 3282 graduate and undergraduate business students at Marshal University between fall 1997 and summer 1999, Anderson, Banks and Leary report that remote site students were least satisfied due to problems with the ITV delivery system.

Students in the Ritchie and Newby (1989) study show no differences in performance (live vs. remote), but perceive less involvement, less ability to ask questions, and less overall enjoyment for students at distance learning sites, while the Seay and Milkman (1994) study of 33 upper division accounting students showed that although remote site students were less likely to participate in class due to cameras, etc., they achieved higher performance levels. Students at both sites in the Seay and Milkman study felt that ITV was conducive to learning and were satisfied with the ITV system, but still preferred live instruction in traditional classroom settings.

Pouzurick, France and Logar (2002) in their study of 143 graduate students in six marketing courses over a two year period report that remote site students were less satisfied with course content, course format, course participation/course activities, and thought the DE mode of instruction to be less effective. Although remote site students accept distance education instruction for convenience, they still prefer live instruction.

Bader and Ray (1999) in their study of 24 students in a MBA course during fall 1997, report that although performance and evaluation of instructors remained the same, on-campus students receiving live course instruction rate the learning environment of distance learning courses more negatively than do remote site students receiving their course instruction via interactive TV in real time.

And finally Heins and Hulse (1996) in their study of grade performance in an undergraduate Organization Theory and Behavior course at the University of Texas-Tyler over a three year period (1993-95) involving 119 students at three sites, found that there was no significant difference in grade performance due to DE technology. Their findings were consistent with the cited results of Arndt and Lafollette (1991) and Pirrong and Lathen (1990), but contrary to the results of Seay and Milkman (1994) which found that remote site students performed better. Heins and Hulse conclude that two way interactive television course instruction in real time is a viable way to meet the needs of a growing non-traditional, older, place bound business student population who may be unable to attend courses on campus in a traditional classroom setting.

\section{RESEARCH METHOD}

A state university in the Pacific Northwest currently offers live instruction to upper division accounting students on the main campus (E) and at two remote sites in a major metro area (D/S) and (L) 100 miles from the main campus, while students located at three rural remote sites, (ML), (W), and (Y), access the same course instruction through distance education (DE) via two way interactive television (ITV) in real time.

One hundred seventeen students in three quantitatively oriented accounting courses taught between 1999 and 2006 were selected for this study. Each course was taught to two student groups, with one group receiving the course instruction live, while one or more groups of students received the same course instruction in real time through distance education via two way interactive television at remote sites. All courses were taught in one/two 
hour modules three/five times per week during a ten week term. Students at each site in each accounting course were administered their exams simultaneously.

A research instrument/questionnaire (See Exhibit) was developed, pretested, and administered to students in each accounting course at all sites (live \& remote) simultaneously. Research questions included differences in student expectations for distant education courses, as well as differences in comprehension, performance, and student satisfaction between students receiving live course instruction in a traditional classroom setting, versus students receiving the same course instruction at remote classroom sites in real time. A series of Likert questions on a five point scale, ranging from (1) strongly agree to (5) strongly disagree were included in the questionnaire to assess student attitudes towards course lecture delivery, student/instructor interaction, exams, observable classroom demonstrations and overhead projections/films, as well as the overall learning experience in distance learning courses involving two way interactive television in real time for the two student groups (live and remote).

The results of the survey were then analyzed for each question using one way analysis of variance (ANOVA) to determine whether any significant differences in student attitudes toward their learning experience in the distance education courses existed for the two student groups (live vs. remote).

\section{RESULTS}

Student attitudes toward distance learning/distance education (DE) ITV course instruction in real time in three quantitatively oriented accounting courses between 1999-2006 were analyzed. In two courses (2000 and 2006) students who received course instruction live in a traditional classroom setting tended to be more satisfied with various aspects of the course than did students attending the same course via two way interactive television in real time at remote sites (Table). The most significant differences in levels of satisfaction involved communication issues such as interaction with the instructor, demonstrations by the instructor, observable overheads/films, and two way oral communication with the instructor during and outside class, with students who received course instruction live indicating they were more satisfied, while students who received course instructions via distance learning at remote sites indicating they were less satisfied.

Traditional college aged students in the 2006 course received course instruction live on the main campus (E), while non-traditional older students at the remote site $(\mathrm{D} / \mathrm{S})$ received course instruction via distance learning (ITV) in real time. The non-traditional students at (D/S) were less satisfied with course instruction via distance learning (ITV) than the college aged students at (E). Students at (D/S) typically received most of their course instruction live in a traditional college classroom prior to this distance learning (ITV) course, while students at (E) typically received most of their course instruction live in a traditional classroom setting on the main campus prior to this course.

Non-traditional older students in one course (1999) who received course instruction via distance learning/distance education (ITV) at one remote site (W) tended to be more satisfied than college aged students who received the same course instruction live in a traditional college classroom setting (Table). The non-traditional students at the (W) remote site typically received most of their course instruction via distance learning ITV prior to this distance learning course, and were more satisfied than the college aged students who received most of their instruction live in a traditional classroom setting prior to this course. The most significant differences in levels of satisfaction (live vs. remote) in the 1999 course involved interaction with the instructor inside and outside the classroom, observable overhead/film and demonstrations. The most significant differences in levels of satisfaction (live vs. remote) in the 2006 course involved interaction/communication with the instructor inside and outside the classroom and observable overheads/films. 


\section{DISCUSSION}

The results of this study on student satisfaction with distance learning/distance education (DE) course instruction via (ITV) in real time are mixed, consistent with the findings of Anderson, Banks and Leary, 2002, and Beaghan, 2006. Non-traditional older students in two quantitatively oriented accounting courses reported a lower degree of satisfaction with course instruction via distance learning (ITV) at remote sites, consistent with the findings of Egan, Welch, et al. (1992), Gunawardena (1992), Kochman (1998) and Clow (1999). Time and place bound nontraditional older students in one quantitatively oriented accounting course reported a higher degree of satisfaction with course instruction via distance learning (ITV) at their remote site, consistent with the findings of Thomerson (1995) and Zarghami (1998) who found a higher degree of student satisfaction with distance learning (ITV) at remote sites due to convenience.

Non-traditional older students in one accounting course at a remote site who typically receive most of their course instruction live, reported less satisfaction with course instruction via distant learning (ITV) and preferred live instruction, consistent with the findings of Seay and Milkman (1994), and Bader and Roy (1999), but accept distance learning ITV course instruction for convenience, consistent with the findings of Pouzarich, France and Logar (2002).

Non-traditional older students at remote sites who typically receive most of their course instruction via distance learning (ITV) tend to rate distance learning (ITV) courses more satisfactorily than do traditional college aged students who typically receive most of their course instruction live in a traditional classroom setting, unless the students are non-traditional older students attending class at a remote site where most of the course instruction is typically presented live by an instructor physically present in the classroom.

\section{IMPLICATIONS AND RECOMMENDATIONS}

Current research on student satisfaction with distance learning/distance education (DE) course instruction via ITV in real time is limited with mixed results. It appears that the perceived degree of satisfaction and value with distance learning ITV courses may be related to the level of student experience with distance learning course instruction, with students who typically receive most of their course instruction live rating distance learning courses less satisfactorily, than do time and place bound non-traditional older students who typically receive most of their course instruction via distance learning at remote sites due to convenience.

More research on student satisfaction (live vs. remote) with distance learning ITV in quantitatively and qualitatively oriented business courses is needed with more focus on factors that may affect the perceived degree of student satisfaction and value with this mode of instruction, including the level of student experience with ITV distance education courses, as well as the level of training and technical support available to instructors who may not be familiar with DE technology.

It appears that distance learning/distance education (DE) course instruction via ITV in quantitatively oriented accounting and business courses may be a viable way of reaching a growing and more diverse student population in the future, including non-traditional time and place bound older students living and working in remote areas who are unable to commute to traditional college campuses, provided we understand the factors that lead to a higher level of student satisfaction and instructor competence with this relatively new mode of course instruction. However, additional research is needed to determine whether live and remote student groups in distance learning accounting and business courses via ITV perceive the same level of satisfaction and value in these courses. It also remains unclear why students (live and remote) in different accounting and business courses may have different attitudes toward distance learning ITV course delivery.

Additional research should also focus on student (live and remote) performance in distance learning/distance education ITV courses, and whether additional instructor training and assistance may mitigate the level of difficulty instructors may experience in transforming course material and exercises into the ITV format, as well as a natural uncomfortableness with this mode of instruction. There are also additional unresolved questions 
concerning a possible difference in students' perceived degree of satisfaction and value with qualitative vs. quantitatively oriented distance education (ITV) course instruction in business and accounting courses.

\section{REFERENCES}

1. Anderson, L., Banks, S., and Leary, P., The Effect of Interactive Television Courses on Student Satisfaction, Journal of Education for Business, (January/February 2002), pp 164-168.

2. Arndt, T. L., and Lafollette, W. R., Interactive Television and the Nontraditional Student, Journal of Education for Business, (January/February 1991), pp 181-185.

3. Bader, M. B., and Ray, S., Using Technology to Enhance Relationships in Interactive Television Classrooms, Journal of Education for Business, (July/August 1999), pp 357-362.

4. Beaghan, J., A Survey of Student Attitudes Toward Distance Learning in Marketing Courses, Journal for Advancement of Marketing Education, Summer 2006, pp 38-43.

5. Clow, K. E., (1999), Interactive Distant Learning: Impact on Student Course Evaluation, Journal of Marketing Education, 21 (2),pp 97-106.

6. Egan M. W., Welch, M., Page, B., and Sebastian, J., (1992), Learning Perception of Instructional Delivery Systems: Conventional and Television, The American Journal of Distance Education, 6 (2), pp 47-55.

7. Gunawardena, C. N., (1992) Changing Faculty Roles for Audiographics and, Online Teaching, The American Journal of Distance Education, 6 (3), pp. 58-71.

8. Heins R.A., and Hulse, D. B., Two Way Interactive Television: an Emerging Technology for University Level Business School Instruction, Journal of Education for Business, (November/December 1996), pp 7477.

9. Kochman, A. F., (1998), An Investigation of Differences in Participant Outcomes Resulting from the Use of Interactive Televised Distance Learning, UMI Microform, 9907752.

10. Pirrong, G. D., and Lathen, W. C., The Use of Interactive Television in Business Education, Educational Technology, (May 1990), pp 49-54.

11. Pouzurick, T., France, K. R. and Logar, C. M., Delivering Marketing Education: an Analysis of Face-toFace versus Distance Education, Journal of Marketing Education, December 2000, pp 80-87.

12. Ritchie, H., and Newby, T.J., (1989), Classroom Lecture/Discussion vs. Live Televised Instruction: A Comparison of Effects on Student Performance, Attitude and Interaction. The American Journal of Distance Education, 3(3), pp 8-17.

13. Seay, R. A., and Milkman, M.I., Interactive Television Instruction: an Assessment of Student Performance and Attitude in an Upper Division Accounting Course, Issues in Accounting Education, Spring 1994, pp 80-90.

14. Silvernail, D., and Johnson, J., (1990), The Impact of Television Instruction on College Student Achievement and Attitudes: A Controlled Experiment, International Journal of instructional Media 17(1), $1-8$.

15. Silvernail, D., and Johnson, J., (1992), The Impact of Interactive Televised Instruction on Student Evaluation of Their Instructors, Educational Technology, 32 (6), pp 47-50.

16. Swift, C.O., Wilson, J.N., and Wayland, J.P., Interactive Distance Education in Business: Is the New Technology Right for You?, Journal of Education for Business, (November/December 1997), pp 85-90.

17. Thomerson, J.D., (1995), Student Perception of the Affective Experience Encountered in Distance Learning Courses, UMI Microform 9531182.

18. Zarghami, F., (1998), Constructs that Contribute to Student Satisfaction for Participating in Graduate Level Courses Delivered by Full Motion Interactive Fiber Optic Communication Network, UMI Microform 9911661. 
Table

\begin{tabular}{|c|c|c|c|c|c|c|c|c|c|c|}
\hline & \multicolumn{2}{|c|}{ ME6/99 } & \multirow[t]{2}{*}{ ANOVA } & \multicolumn{3}{|c|}{$\frac{346 / 00}{\text { MEANS }}$} & \multirow[t]{2}{*}{ ANOVA } & \multicolumn{2}{|c|}{$\begin{array}{l}\text { 430/06 } \\
\text { MEANS }\end{array}$} & \multirow[t]{2}{*}{ ANOVA } \\
\hline & $\underline{\mathrm{D} / \mathrm{S}}$ & $\underline{\mathrm{W}}$ & & $\underline{\underline{W}}$ & $\underline{Y}$ & ML & & $\underline{E}$ & $\underline{\mathrm{D} / \mathrm{S}}$ & \\
\hline Question & & & & & & & & & & \\
\hline Informative & 3.67 & 3.25 & 0.24 & 1.57 & 1.45 & 2.00 & 0.75 & 1.85 & 2.50 & 2.00 \\
\hline Understood & 3.67 & 3.00 & 0.75 & 2.14 & 2.00 & 2.67 & 0.99 & 1.69 & 2.67 & 5.36 \\
\hline Cases & 3.00 & 2.50 & 0.53 & 1.86 & 1.55 & 1.67 & 0.60 & 1.85 & 2.67 & 2.66 \\
\hline Interaction W/Instructor & 3.33 & 2.25 & 2.79 & 2.14 & 1.82 & 2.00 & 0.28 & 1.46 & 3.42 & 18.20 \\
\hline Interaction W/Classmates & 2.50 & 2.25 & 0.08 & 1.57 & 1.36 & 2.00 & 1.07 & 1.92 & 2.83 & 3.89 \\
\hline Demonstrations & 3.67 & 2.50 & 2.12 & 2.00 & 1.64 & 2.67 & 3.24 & 1.46 & 2.83 & 15.98 \\
\hline Overheads/Films & 3.50 & 2.75 & 0.53 & 2.14 & 1.82 & 2.33 & 1.06 & 1.52 & 2.75 & 12.06 \\
\hline Communication-All & 2.83 & 2.50 & 0.15 & 2.00 & 1.64 & 2.33 & 1.09 & 1.77 & 3.25 & 16.96 \\
\hline Participation & 3.00 & 2.75 & 0.11 & 2.00 & 1.55 & 2.00 & 0.91 & 2.31 & 2.64 & 0.48 \\
\hline Exams & 3.83 & 3.25 & 0.37 & 1.71 & 1.45 & 2.00 & 0.88 & 1.31 & 2.08 & 5.51 \\
\hline Communication-Out & 3.67 & 2.25 & 3.19 & 2.43 & 2.18 & 2.33 & 0.13 & 1.54 & 3.00 & 23.17 \\
\hline Expectations & 3.17 & 3.00 & 0.06 & 1.71 & 1.73 & 2.67 & 1.27 & 2.17 & 3.25 & 5.18 \\
\hline Learning Experience & 3.17 & 3.00 & 0.04 & 2.14 & 2.18 & 2.33 & 0.03 & 2.85 & 3.17 & 0.40 \\
\hline
\end{tabular}

\section{EXHIBIT}

Please indicate the extent to which you agree/disagree with the following statements about this course by circling the number that most closely approximates your position (if applicable).
Strongly
1
Agree
2
$\underset{4}{\text { Disagree }}$
3

Strongly Disagree

5

Lectures were informative.

Lectures were clearly understood.

Case discussions/analysis allowed for my full participation.

Interaction with my instructor was easily facilitated.

Interaction with classmates during class discussions was easily facilitated.

Classroom demonstrations by the instructor were easily observable.

Classroom overhead projections/films were easily observable.

Two-way oral communication with the instructor was easily facilitated.

Class/group projects/assignments were easily facilitated.

Taking exams was easily facilitated.

Communication with the instructor out of the classroom (i.e., during office hours) was easily facilitated

Overall, the learning experience in this class met my prior expectations

The learning experience in this class was not affected by the distance learning component

$\begin{array}{llll}2 & 3 & 4 & 5 \\ 2 & 3 & 4 & 5 \\ 2 & 3 & 4 & 5 \\ 2 & 3 & 4 & 5 \\ 2 & 3 & 4 & 5 \\ 2 & 3 & 4 & 5 \\ 2 & 3 & 4 & 5 \\ 2 & 3 & 4 & 5 \\ 2 & 3 & 4 & 5 \\ 2 & 3 & 4 & 5 \\ 2 & 3 & 4 & 5 \\ 2 & 3 & 4 & 5 \\ 2 & 3 & 4 & 5\end{array}$


NOTES 